\title{
Alisdair D J MacPherson, The Floating Charge
}

Nicholas Grier

This is an Accepted Manuscript of an article published by Edinburgh University Press in Edinburgh Law Review. The Version of Record is available online at:

http://www.euppublishing.com/doi/abs/10.3366/elr.2021.0729 


\title{
The Floating Charge.
}

\author{
Alisdair MacPherson
}

Edinburgh Legal Education Trust 2020 pp.255

Back in 1961, when Scots law first admitted that creature of English chancery lawyers from the 1870 s, the floating charge, business in general welcomed the change. Scots businesses had been at a disadvantage relative to English ones in not being able to grant floating charges. English businesses could offer security over their ever-changing assets in a way denied to Scots businesses. The perceived unfairness was at last being remedied. No longer would there need to be "work-rounds". No more would Scottish businesses have to be registered in England to enjoy a more commercial set of laws.

It would be nice to think it was plain sailing thereafter. Sadly, it has not been. The floating charge manages to be on the intersection of corporate law, property law, insolvency law and, with the advent of administration, the rescue culture. Everyone can see the need for floating charges, but fitting them into Scots law has been consistently problematic. Furthermore, according to MacPherson's excellent new book on the subject, it probably always will be.

The first problem was that there was no method of enforcement of the floating charge. That was fixed in 1972 by allowing receivers. Then the respective rights of fixed security holders, floating charge holders, liquidators and creditors effecting diligence, not to mention preferential creditors and prescribed part creditors, needed to be thrashed out. The position was not helped by enigmatic legislation, judicial misunderstandings, (notably of the phrase "effectually executed diligence") and the reluctance of Scots law to recognise any type of right in property other than real rights and personal rights. There were practical problems too. Scots law rightly requires that securities should require publicity, but even though a floating charge can act as a heritable security over a company's property in Scotland, the Register of Sasines and the Land Register cannot, at least at present, show that interest in their records.

Reading MacPherson's detailed analysis of the many illogicalities, inconsistencies and difficulties thrown up by floating charges and receivership, it is perhaps fortunate that receivership is now so rare and is now replaced with administration. It is also ironic that although floating charges were once seen as good security for a lender, floating charges, though still worth having, are not as useful as they were. Many smaller companies have few assets. They lease their equipment or buy it on hire purchase. They factor their debts. As from last December, HMRC returned to being a preferential creditor. The human capital in a company may be more important, and harder to retain, than the stock that a receiver once could sell. There is even talk by the City of London Law Society of the abolition of the floating charge. But even so, floating charges will be with us for many years to come.

MacPherson's book is in two parts, the first dealing with the nature of the floating charge itself, what attachment does and what it attaches to, and how the floating charge may be enforced. The second explains how attachment affects the different types of property in Scotland. There is a masterly analysis of that most problematic of cases involving the floating charge, Sharp v Thomson. This was a classic example of a hard case making bad law, the apparent unfairness for the Thomsons in paying for their house, and then losing it to the receiver, outweighing the fact that there was unsatisfactory conveyancing practice by the 
Thomsons' solicitors. Perhaps what MacPherson underplays is the fact that had the House of Lords found for the receiver, the consumer lobby would have erupted. And there's the human element. If we were the Thomsons, what would we have wanted? The right to sue our lawyers for not doing their job properly, or the right to stay in the flat of our dreams, where our furniture was - and which we'd already paid for?

There can be no article or case on the Scottish floating charge that MacPherson has not read. $\mathrm{He}$ is exceedingly well informed on the subject. He concludes, entirely reasonably, that the Scottish floating charge is a charge sui generis which does not fit well with Scots law. It has to be taken on its own terms, and we have to live with it. But curiously, MacPherson omits one point: the Scottish floating charge clearly is pretty unsatisfactory in many ways, but it does work, after a fashion. Despite what was said earlier about the floating charge not being very effective, banks still take floating charges, and the ability to borrow against assets other than heritage is useful for companies which do not own any heritage. The 21 day registration gap is not ideal, but there is at least publicity. Though it is not a point in its favour, precisely because the law is not absolutely clear, potential disputes are resolved commercially and probably more quickly than if the lawyers were involved - and given the history of judicial intervention in floating charges, maybe this is a good thing.

MacPherson's book is perhaps heavier on the problems with the Scottish floating charge rather than their solutions. If there were to be improvements to the law relating to Scottish floating charges, there would need to be specific legislation to allow for this. Any proposed legislation could perhaps set out exactly what a floating charge can and cannot do, how it may be enforced, to what and when it attaches, how publicity requirements are managed, and where the floating charge holder stands relative to other creditors. The auguries for this at Holyrood are not good. The proposed improvements in the Bankruptcy and Diligence etc (Scotland) Act 2007 were dropped. The Moveable Transactions Bill seems to be going nowhere, at least for the time being.

This book is a work of considerable legal scholarship. It is not a practical book telling the reader how to draft or register a floating charge. Nor does it pretend to be. But for an analysis of the floating charge in Scotland, and its anomalous nature, it is so far unbeaten. Should there be an important case on floating charges in the Inner House, this would be the book their Lordships would be reading at the weekend. They would certainly profit from the exercise.

Nicholas Grier 